\title{
Capacitor Discharge Welding of Aluminium Studs
}

Tomáš Kramár ${ }^{1}$, Ladislav Kolařík ${ }^{2}$, Marie Kolaříková ${ }^{2}$, Martin Sahul ${ }^{1}$, David Pospíšil ${ }^{3}$

${ }^{1}$ Slovak University of Technology in Bratislava, Faculty of Materials Science \& Technology in Trnava, Paulinska 16, 91724 Trnava, Slovak Republic, tomas.kramar1@gmail.com

${ }^{2}$ Czech Technical University in Prague, Faculty of Mechanical Engineering in Prague, Technická 4, 16607 Prague 6, Czech Republic

${ }^{3}$ Proweld s.r.o.., Štěpáňákova 6 Kunčice, 71900 Ostrava 19, Czech Republic

The paper deals with capacitor discharge welding of aluminum studs type AIMg3 on two different materials (aluminum sheet of the same chemical composition with a thickness of $1.5 \mathrm{~mm}$, and the magnesium sheet, material AZ61 and thickness $1 \mathrm{~mm})$. Influences of welding parameters on the mechanical properties of the weld joints and the creation of typical defects were examined. For assessing the quality of weld joints, a series of tests were made: micro hardness test, bend test, torque test, test of macro and microstructure and SEM analysis on the electron microscope. The results are presented in the paper including suggestions for welded joints of required quality.

Keywords: Aluminum Alloy; Magnesium Alloy; Stud; Stud Welding

\section{Acknowledgement}

The research was supported by STU university grant project for young researchers Laser welding of Mg alloys no. 1320 and by the Czech Ministry of Education, Youth and Sport within the frame of project SGS CVUT SGS13/187/OHK2/3T/12

\section{References:}

[1] VÁLOVÁ, M., KOLAŘÍK, L. (2009) Perspektivní metody spojování material. In MM průmyslové spektum, ČVUT v Praze FS,

[2] Hudec Z, (2012) Gas metal Rapid Arc welding potential, Manufacturing Technology, ISSN 1213-2489

[3] Svorníky pro přivařování - kondenzátorové [cit. 2013-11-10]. Available at: http://www.proweld.cz/ole/katalogdin32501_komplet_2010.pdf

[4] Kolaříková M, Kolařík L, Kovanda K, Hrabina R, (2013) Welding of normalized heat treated steels S355NL large thicknesses by method FCAW, Manufacturing Technology, ISSN 1213-2489

[5] HBS Bolzenschweiss-Systeme GmbH \& Co. KG [cit. 2013-1-10]. Available at: http://www.hbs-info.com/basics/processes/stud-welding.html

[6] HRIVŇÁK, I.: Zváranie a zvaritel'nost' materiálov. Bratislava: STU, 2009. ISBN 978-80-227-3167-6

[7] PRŠKOVÁ, V. Ultravysokocyklová únava horčíkových zliatin. Žilinská univerzita, Žilina 2008. Vedoucí dizertační práce prof. Ing. Otakar Bokůvka, PhD.

[8] What is stud welding [cit. 2013-1-10]. Available at: http://www.thomas-welding.com/technique/process.htm

[9] Stud Welding [cit. 2013-1-10]. Available at: http://www.epitech.com.au/ Epitech/ Portals/0/why\%20studwelding.pdf

[10] ALFUN. Metal service center [cit. 2013-11-10]. Available at: http://www.alfun.sk/kontakty/alfun-sk-s-r-o

[11] PALEČEK, P., CHALUPOVÁ, M., LUKÁČ, P., TROJANOVÁ, Z. (2005) Vplyv teploty na lomové charakteristiky vybraných horčíkových zliatin. In Materials Engineering vol. 12, issue 3, p. 117-122. ISSN 1335-0803

[12] Arc stud welding fundamentals [cit. 2013-11-10]. Available at: http://www.millerwelds.com/pdf/ArcStudWelding.pdf

[13] Sahul M, Turňa M, Šugárová J, Sahul M, (2013) Influence of laser welding aluminium alloy on mechanical properties of welded joints, Manufacturing Technology, ISSN 1213-2489 